\title{
Global Value Chain in the Post-COVID Era: Implications for Regional Cooperation of ASEAN and China
}

\author{
Min He \\ School of International Economics, China Foreign Affairs University, Beijing, China \\ Email: hemin@cfau.edu.cn
}

How to cite this paper: He, M. (2021). Global Value Chain in the Post-COVID Era: Implications for Regional Cooperation of ASEAN and China. Open Journal of Political Science, 11, 739-751. https://doi.org/10.4236/ojps.2021.114047

Received: September 5, 2021

Accepted: October 26, 2021

Published: October 29, 2021

Copyright $\odot 2021$ by author(s) and Scientific Research Publishing Inc. This work is licensed under the Creative Commons Attribution International License (CC BY 4.0).

http://creativecommons.org/licenses/by/4.0/

\section{(c) (i) Open Access}

\begin{abstract}
The COVID-19 pandemic has delivered a profound shock to the Global Value Chain. The geographic make-up of most GVCs has become regionalized and localized rather than globalized due to the outbreak. In order to strengthen the regional supply chain and value chain cooperation between China and ASEAN, especially in this post-COVID-19 era, to achieve economic recovery, this paper tries to sum up how the COVID pandemic impacts the global value chain, and then discuss the position of China and ASEAN countries in the global value chain by calculating the proportion of intermediate goods on global, regional, and country-level, using the newly available data; thus, shed light on the policy implication for the future cooperation of China and ASEAN to build a "regional" global value chain.
\end{abstract}

\section{Keywords}

Global Value Chain, Regional Value Chain, COVID-19, China and ASEAN Cooperation

\section{Introduction}

The COVID-19 pandemic has delivered a profound shock to the Global Value Chain (GVC). The geographic make-up of most GVCs has become regionalized and localized rather than globalized due to the outbreak. Despite a drop in global trade because of the epidemic, the trade between China and ASEAN has grown, and ASEAN has overtaken the EU and become China's largest trading partner. Therefore, it has become an essential and urgent issue to strengthen the regional supply chain and value chain cooperation between China and ASEAN, especially in this post-COVID-19 era, to achieve economic recovery. 
Under the new international division of labor in global industrial development, China and ASEAN have played crucial roles in the global value chain and global production networks. This paper tries to sum up how the COVID pandemic impacts the global value chain, and then discuss the position of China and ASEAN countries in the global value chain using the newly available data; thus, shed light on the policy implication for the future cooperation of China and ASEAN to build a "regional" global value chain.

The paper will be structured as follows: Section 2 will be a brief literature review of the current research of the global value chain. Section 3 will discuss how the COVID-19 impacts the GVC development and the global value chain governance in the post-COVID Era. Section 4 illustrates the position of China and ASEAN countries in the global value chain by describing the changing pattern of intermediate goods trade. Finally, Section 5 offers some policy implications for the future cooperation of China and ASEAN countries on the regional value chain to ensure a sustainable economic recovery.

\section{Literature Review: Global Value Chain}

The concept of Global Value Chain was introduced in the early 2000s coming from the analysis of trade and industrial organization as a value-added chain in the international business literature (Gereffi, 1994; Gereffi, et al., 2001; UNIDO, 2002). Typically, a value chain includes the activities such as design, production, marketing, distribution, and support to the final consumer. These activities can be distributed within the same firm or divided among different firms, which increasingly located in several countries along with the development of globalization and regionalization, and then regarded as "global value chain".

The researches on global value chain were mainly on two aspects: the main drivers of GVC and the governance of the GVCs. The main reason why firms fragmented their production across countries was lower trade costs (De Backer, \& Miroudot, 2013). In the case of goods trade, trade costs included land transport costs in exporting countries from factory to port, port costs, international freight and insurance costs, tariffs and duties, costs associated with non-tariff measures, as well as costs spent in importing countries such as port costs, land transport costs from port to the importers or final consumers. In the case of services trade, trade costs included R\&D and training costs, transport costs, transactions costs, and trade barriers (mainly non-tariff measures) such as access to national treatment, restrictions on the movement of natural persons, etc. Other important costs related to global value chains were production costs (such as land, labor, and raw materials), marketing and distributing costs(such as channel developing expenses), and coordination costs as geographically dispersed activities have to be managed in a consistent way.

Technological progress, first of all, has greatly decreased all kinds of cost both in goods and services trade. The improvement of Information Communication Technology (ICT) and infrastructure has increasingly allowed the coordination 
and monitoring of activities located at a larger distance. Transport and communication costs have also been decreased due to technological advances such as the container or the Internet. Furthermore, trade and investment liberalization as well as regulatory reforms in key transport and sectors has been another important driver of global value chain. Beyond technological change and regulatory reforms, the drivers also came from the demand side. The high growth rates in new emerging economies in East Asia have increased the size of world demand and boosted international trade, in which not only the trade in final goods and services has increased but also trade in intermediate goods.

The research on governance of the GVCs was mainly discussed from three levels. The first level was from country level, in which researchers illustrated the characteristics of increasing fragmentation of production across countries so that the policymakers could apprehend the interconnectedness of economies (Sturgeon \& Memedovic, 2010). The second level was from industry or product level. The specialization of countries in their tasks of producing a specific product or in business functions in a specific industry were compared to see how they competed on economic roles within the value chain, so that the policymakers could close the gap between policies and the reality of businesses. The third level of the GVC governance studies focused on discussing the structure of GVCs (Gereffi et al., 2005), such as the role of networks, global buyers and suppliers, to identify firms and players that control and coordinate activities in production networks. In this level, the policymakers not only discuss the policy coordination on industry-level, but also on firm-level. Gereffi et al. (2005) provided a theoretical framework for the value chain analysis and described 5 different types of global value chain governance. As it has been shown in Figure 1, the micro-foundation of GVC governance were firms, especially big multinational corporations who played as Lead Firms in GVCs.

There were two ways in general that used by the researchers to illustrate the increasingly fragmented production process across countries. At the very beginning, as goods-producing industries have been at the forefront of GVC development, the increased demand for specialized intermediate goods (such as parts and components, and partially manufactures subassemblies) cross borders have drawn a border range of establishments. Countries which have been very deeply integrated into increasingly complex and dynamic divisions of labors would have a greater proportion of intermediate goods ${ }^{1}$ in total trade, indicating greater participation of GVC. Furthermore, researchers used the proportion of parts and components products in total trade to show the position of the GVC from country level. The greater of the ratio is, the higher the position of the country in the global value chain is.

However, there was a growing awareness that there were not only inputs from one country to produce intermediate and final goods. In order to capture

${ }^{1}$ According to the Classification by Broad Economic Categories (BEC), goods are classified into capital goods, intermediate goods and consumption goods. In intermediate goods, there are primary goods, semi-finished products, and parts and components products included. 


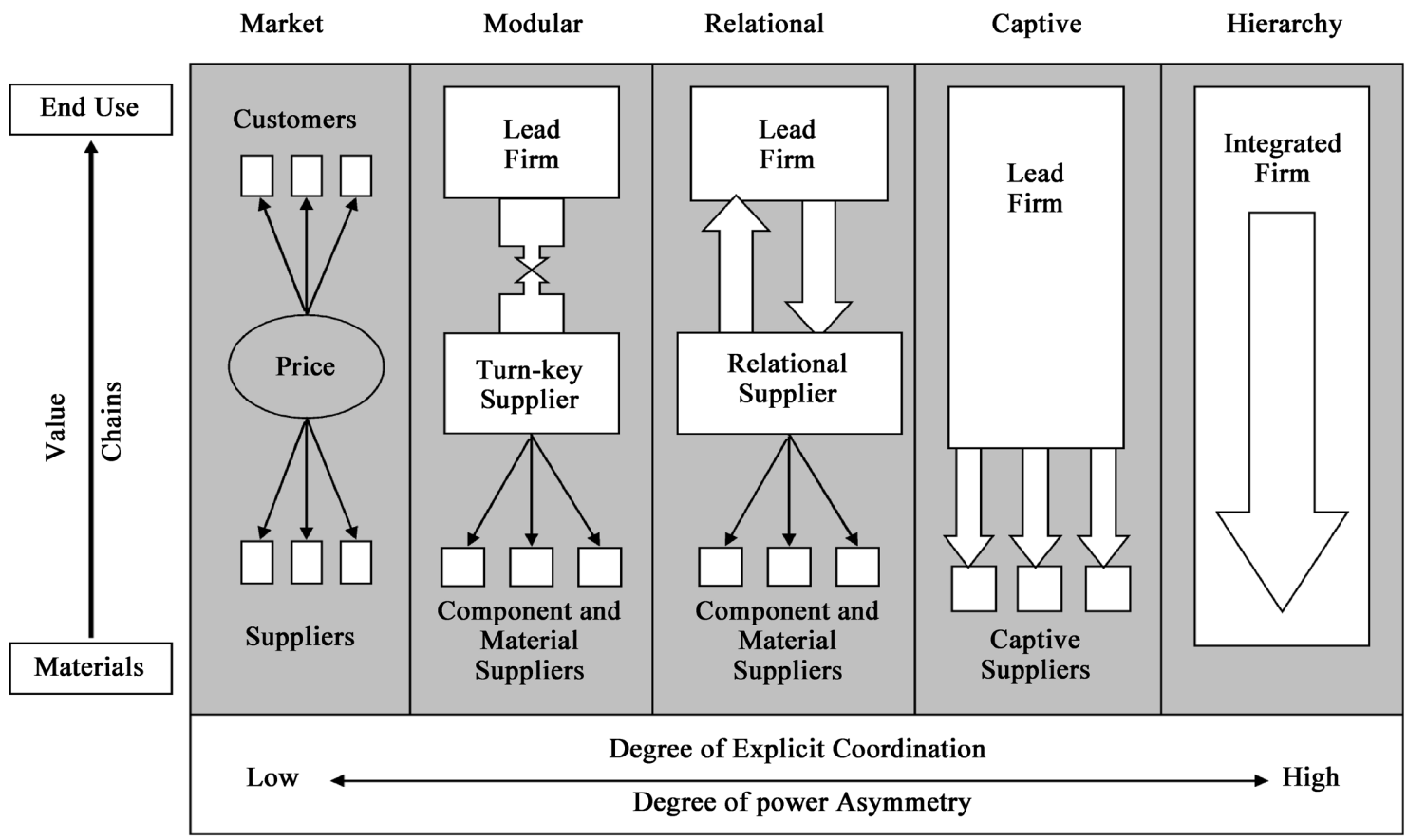

Source: Gereffi et al. (2005).

Figure 1. Five global value chain governance type.

the detail characteristics from industrial and product level, Koopman, Wang and Wei (2012) integrated input-output tables to international production and trade networks to describe domestic inputs and foreign inputs used in producing the exports, namely Forward_participation and Backward_participation. The OECD, in cooperation with WTO, has built a TiVA database based on this approach, from which could calculate the measurement indexes of global value chain of 58 countries accounting for more than $95 \%$ of world output. However, the latest data in this database has been updated in 2018 which based on the data of the year 2017, before the outbreak of the epidemic.

In order to provide newly available data and analyze how COVID-19 impact the GVC, we calculate the proportion of intermediate goods on global level, regional level and country level respectively, to discuss the structure change of the world economy and the position of China and ASEAN countries.

\section{Global Value Chain in the Post-COVID Era: Governance for Reliability}

\subsection{How Are GVCs Impacted by COVID-19?}

Figure 2 shows the share of intermediate goods in the world total goods trade from 2002 to 2020 . We could see that, first of all, although the ratio of intermediate goods has been slightly getting down since 2011, it's still accounting for more than $50 \%$ of the world total trade in $2020(52.45 \%)$. This indicates that Global Value Chain still captures the characteristic of the world economy. What's more, this round of decline actually has began before the COVID-19 in 


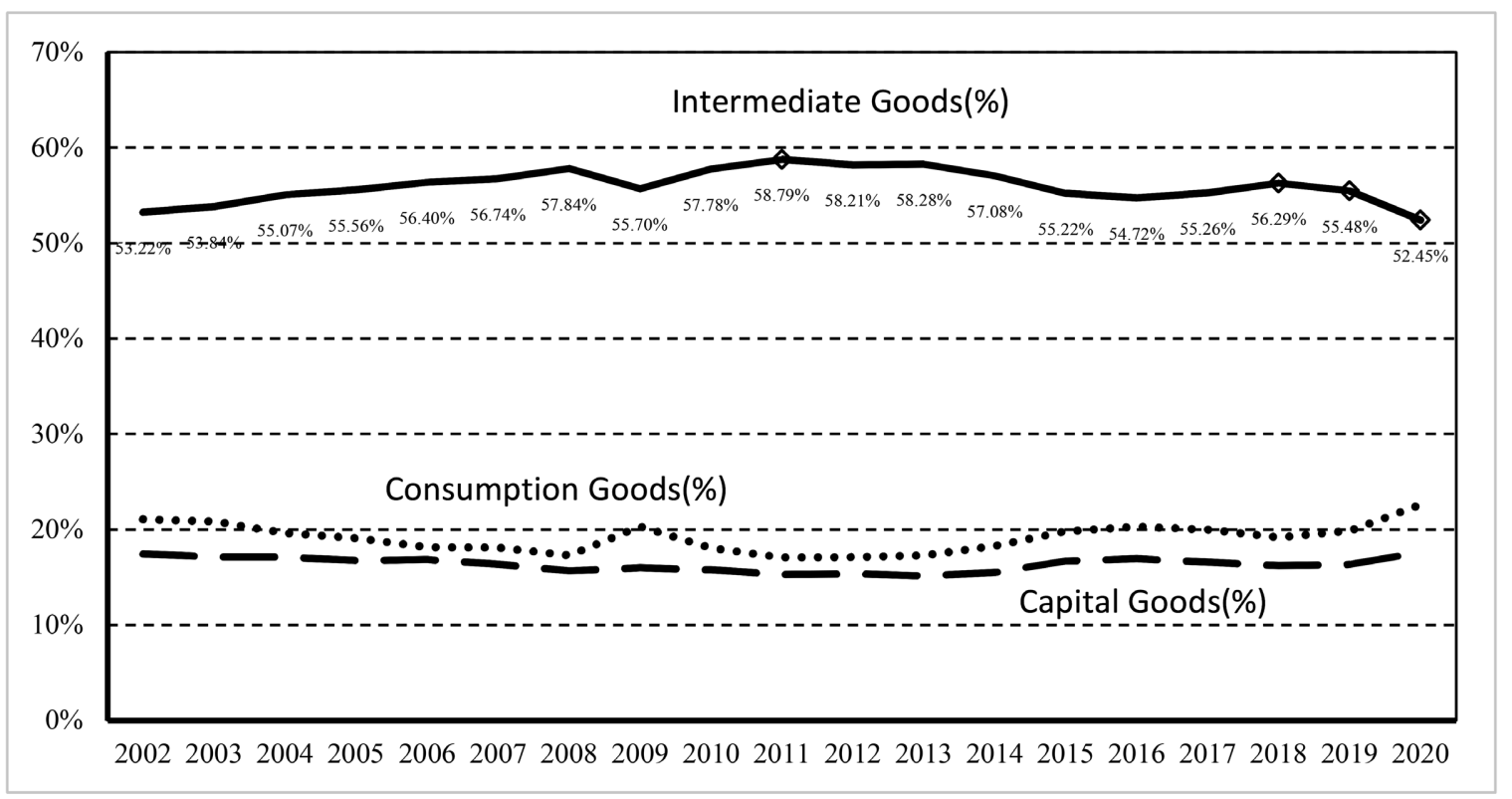

Data Source: UN Comtrade; \%: Share of Total Trade.

Figure 2. GVC and structure change of world economy (total).

early 2020, which could date back to even in 2018 . That is to say, before the pandemic, the new round of anti-globalization and trade protectionism, especially the US-China trade tension, has made countries such as the US has drawn their manufacturing back to their own countries to produce their own final goods directly (which includes consumption goods and capital goods) and encouraged the consumers to buy products produced in their own country, so that the share of the intermediate goods trade has been getting down. Since then, the COVID-19 seems only accelerating this trend but not the key driver of this decline trend.

Figure 3 shows the ratio of intermediate goods on regional level from 2002 to 2020. We could observe the similar pattern like Figure 2. First of all, the world manufacturing factory East Asia's ratio of intermediate goods has been getting larger, as the NAFTA and EU's ratio of intermediate goods has been getting down (especially NAFTA), showing a big picture that, the structure of world economy and GVC is getting more regional. Moreover, this developing trend actually had begun before the pandemic, even earlier in 2018 and 2019. Meanwhile, due to the reliable anti-epidemic policies and protective measures adopted by East-Asian countries, especially China (priority has been given to the resumption of work and production to support the global value chain), it turned out that the GVC has become more rely on East Asia. In another word, East Asia has been playing an even more important role in GVC because of the epidemic.

To sum up of the data analysis above, it was obvious that, there was a decline in fragmentation of production across borders actually prior to COVID-19 crisis. Since 2011, the expansion of GVCs shown by share of intermediate goods has stopped (Figure 2). Less trade in intermediate goods indicated that firms 


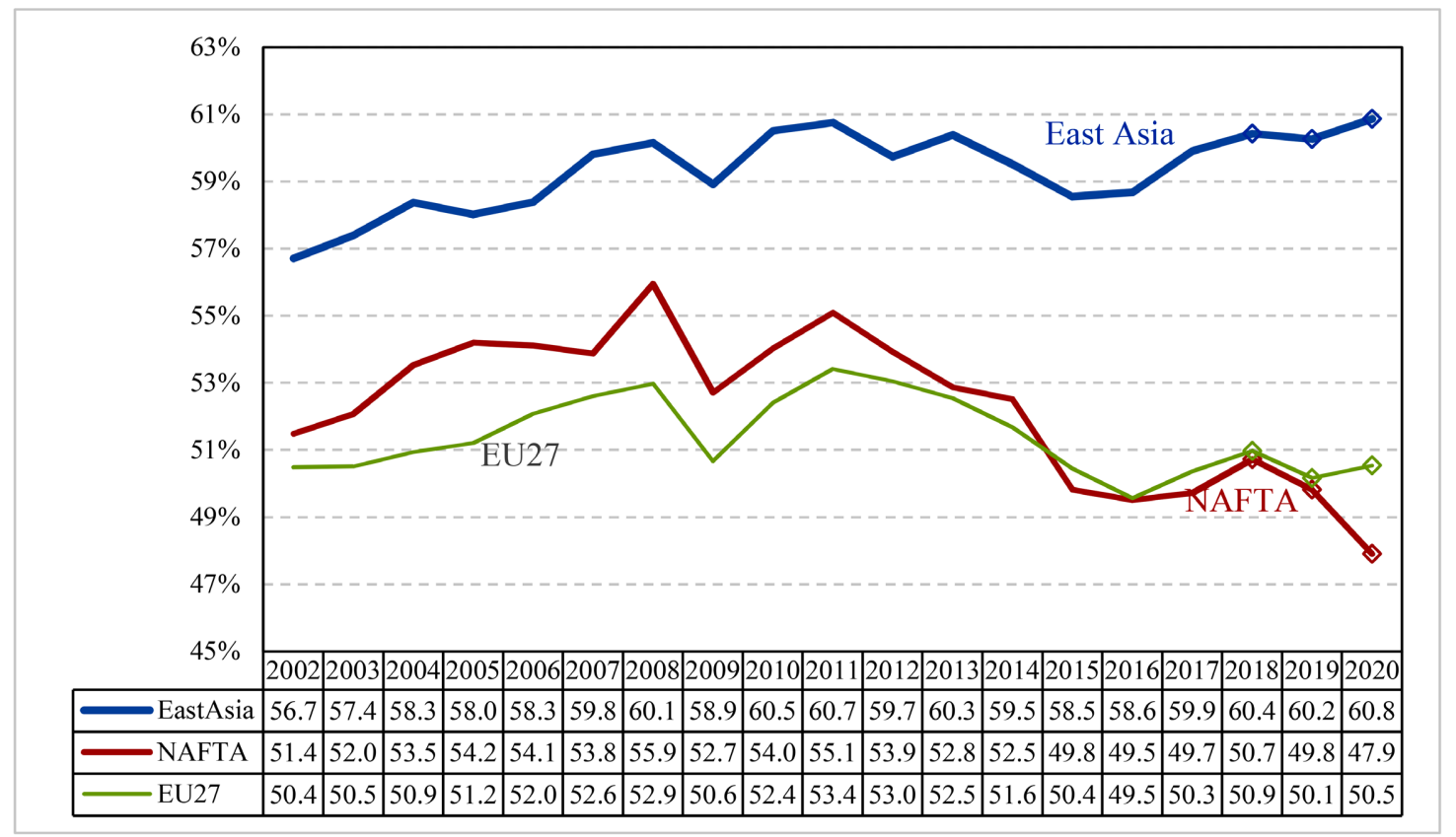

Data Source: UN Comtrade. \%-Intermediates Trade/Total Trade.

Figure 3. GVC and structure change of world economy (region).

have been reducing their use of foreign inputs, and tending to produce closer to consumers and rely less on offshoring, while still providing better products and services. Structural shifts such as the digitalization of economies, the servicification of manufacturing and consumer preferences for more sustainable production processes were important reasons. Higher trade costs and rising policy uncertainty because of trade tensions and rising protectionism were also important drivers. The pandemic in early 2020 has accelerated this trend. However, we do not foresee long-term changes yet; the structure of the world economy as well as the fundamental principles of GVC governance has not changed substantially.

As a global health crisis, The COVID-19 pandemic has surely delivered a profound external shock to global value chains. What's more, compared to the external shocks such as the 2008 Sichuan earthquake, the 2011 Tohoku earthquake and tsunami, the impact of the COVID-19 pandemic has been more intense, with much larger geographic and industrial scope, and longer duration.

It first impacted the production of firms in GVCs in several ways. Production was stopped or disrupted because firms were directly affected by the presence of the virus at production sites. For example, January 2020, when China decided to lock down the city of Wuhan and start taking measures to prevent the spread of the virus to the rest of the country, manufacturing companies in the rest of the world were quickly hit. Car manufacturer Hyundai halted all production in Korea on 7 February 2020 due to a shortage of components coming out of China. For the firms whose production site was not affected by the virus also confronted a serious problem, that their sourcing inputs from other countries could be affected. Besides, not only the international flight and liners have been halted, 
but also the domestic transport networks and logistics have been disrupted. So far, the maritime freight has been increased from 2000 USD to 15,000 USD per $40 \mathrm{HQ}$, by 6.5 times from Guangzhou port to Rotterdam. Governments measures such as restriction of the movement of people, border controls led to the disruption of the Global Value Chain from supply side as well.

On the demand side, there has been a surge in demand for medical supplies such as facial masks, disinfecting tissues, etc., as well as a shift in demand for consumers of healthy, green food products, while a decrease for other final and manufacturing goods because of the home quarantine policies. Moreover, lower demand for final or manufacturing products in a given country reduced demand for inputs produced in other countries within GVCs, affecting multiple locations at once when simultaneous reduction in demand in many countries.

Therefore, the arrangement for the GVC governance has been changed from lower cost to reliability in the long term. Diversifying their production locations for stable inputs has become more important for firms than production locations of lower cost. As a result, countries that could maintain stable open policies, effectively control the epidemic, and relatively closer as well as with fewer transport risks, have become the first choice for multinational corporations to further diversify their global supply chains so that they can ensure the long-term survival and sustainable development of their GVCs.

\subsection{Global Value Chain in the Post-COVID Era: Governance for Reliability}

This governance for reliability of GVC in the post-COVID era requires multinational enterprises (MNEs) develop their own risk management strategies (OECD, 2020) in practice such as securing alternative supply and distribution channels, arranging for reasonable production capacity, engaging in new partnerships, and expertly handling relevant information, etc. As a consequence, the lead MNEs have to entails their managerial practices. For example, greater investment into information systems and analytics this is getting essential for lead MNEs to quickly access relevant information, perform scenario analysis, and design appropriate responses to exogenous shocks. Empirical evidence shows that lead MNEs such as Nike relied on predictive analytics to adjust production and re-route distribution, and as a result managed to moderate COVID-19 disruptions to their value chains.

Second, relational governance in GVCs has become more important to improve information flows, secure commitments, and promote entrepreneurial action. On one hand, lead MNEs unite firms with compatible goals and strategies, and facilitate a coherent GVC-level response to exogenous challenges. On the other hand, it is also of great importance for lead MNEs to strengthen their connections with home and host country regulators who possess the power to shape local, national, and international responses to external shocks.

Furthermore, the management goal of the lead MNEs has been changed to achieve the maximum efficiency instead of lower cost. Stable sourcing inputs 
and production locations, confirming demand order makes higher efficiency of GVCs. Only the GVC be sustainable could ensure the long-term survival of the MNEs. So, multilateral and cross-industry collaborations would be also helpful to ensure the supply and demand shifts.

For policymakers, in order to be more reliable for GVC governance, maintaining an open, stable trade and investment regulatory environment is critical and at the first place for GVCs' development. Second, knowledge sharing platforms using digital technologies for risk management and practices discussions would be very useful and helpful, not only for companies but also for governments and civil society, to identify best practices to manage risks. Moreover, reshoring policies include subsidies, or supply chain nationalization in certain products for health and security reasons would also ensure the reliability for GVCs. But such interventions would have additional costs, trade-offs and risks. Furthermore, as the geographic scope of GVC is now getting regional, it would be helpful to include provisions for the smooth operations of GVCs in regional trade and investment agreement to build more resilient regional production networks.

\section{The Position of China and ASEAN Countries in Global Value Chain}

Figure 4 calculates the ratio of intermediate goods trade in total trade of China and ASEAN countries using the latest available trade data, reflecting the extent of their GVC participation. According to the results, China and ASEAN countries have been greatly participated in GVC, as all the ratios except Cambodia were greater than $50 \%$. However, the GVC participation extent was different. In 2019 , Brunei ranked at the $1^{\text {st }}$ place with the proportion of $77.51 \%$. The GVC participation of Indonesia, Laos, Malaysia, Philippines, Singapore, and Thailand were $68.50 \%, 67.34 \%, 67.10 \%, 62.72 \%, 59.02 \%$ respectively, all higher than $58.50 \%$ of China. While the ratios of Vietnam and Cambodia were 56.35\%, $41.33 \%$, lower than China. This, to some extent, indicates complementary of China and ASEAN countries in the global value chain.

Figure 5 shows the GVC position of China and ASEAN countries. According to the calculation results, in 2019, Singapore, Philippines, Malaysia and Vietnam's ratios were $38.64 \%, 33.49 \%, 31.00 \%$, 24.26\% respectively, all higher than $22.74 \%$ of China. While Thailand, Indonesia, Brunei, Laos, and Cambodia's ratios were $19.16 \%, 10.91 \%, 7.24 \%, 6.56 \%, 3.54 \%$ respectively, lower than China. This also reflects great complementary of China and ASEAN countries in the global value chain, as they were at the different position in Global Value Chain. On average, China has been at the lower end of GVC than ASEAN countries (26.96\%). However, comparing to the higher ratio of GVC participation, the GVC position ratio of both China and ASEAN countries were smaller, indicating relatively lower-end position of both China and ASEAN countries in global value chain. 


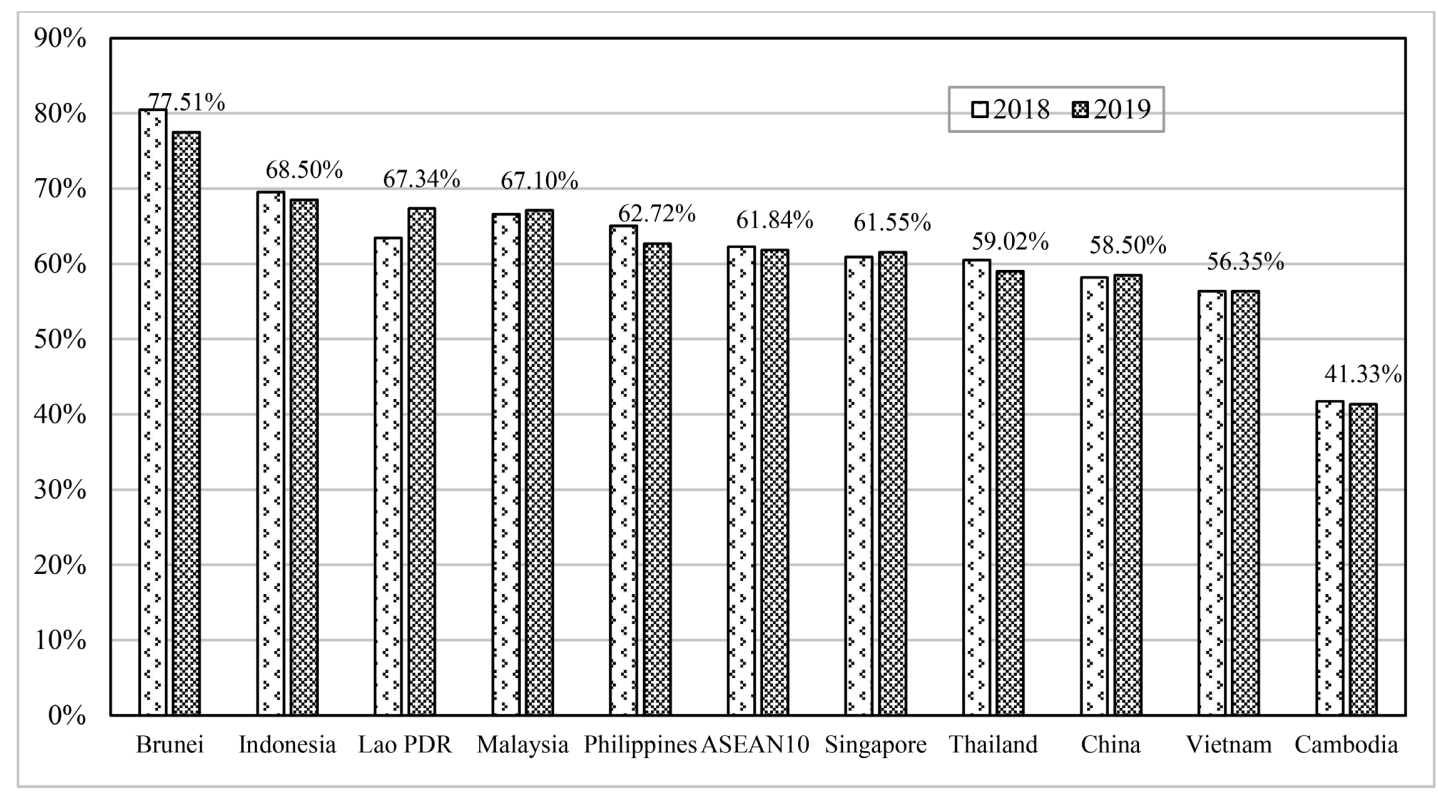

Data Source: UN Comtrade. \%-Intermediates Trade/Total Trade.

Figure 4. GVC Participation of ASEAN and China

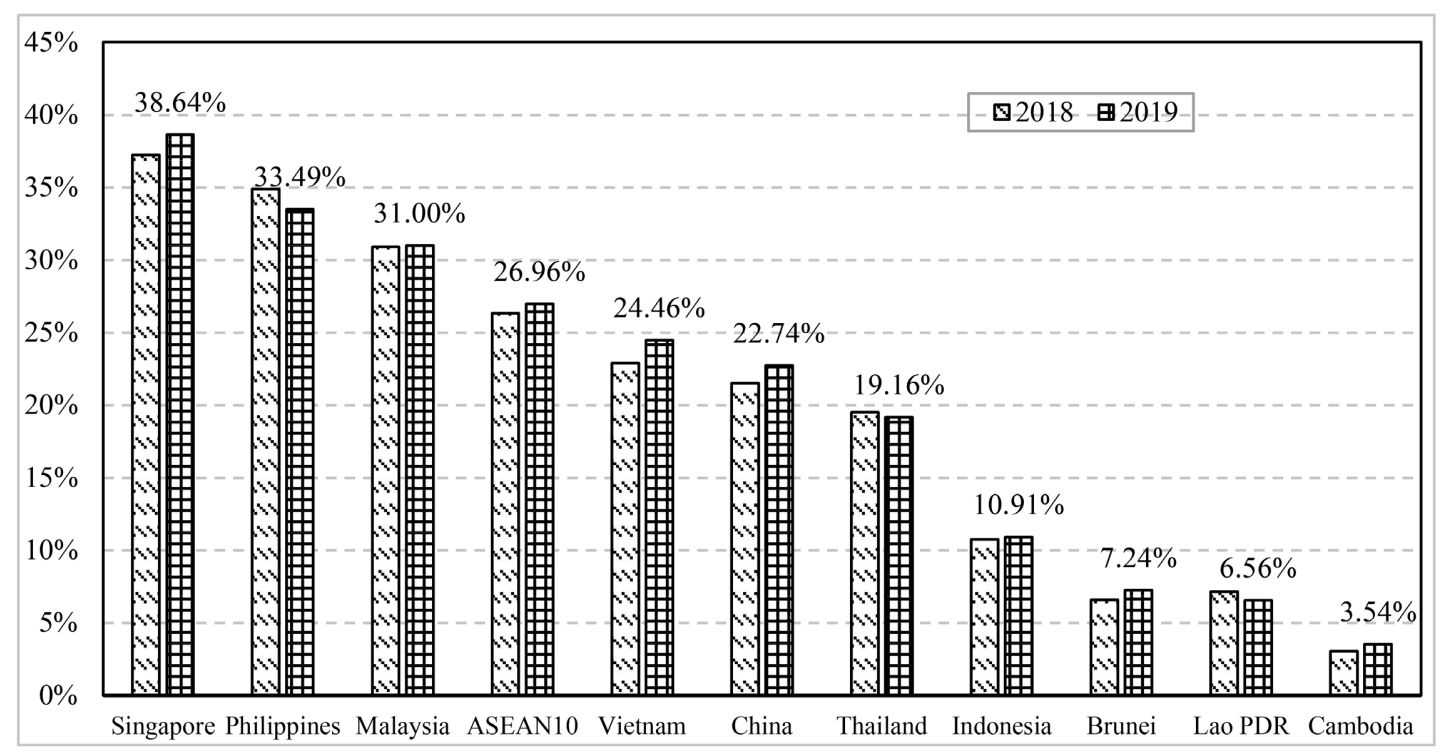

Data Source: UN Comtrade. \%-parts and components products trade/total trade.

Figure 5. GVC Position of ASEAN and China

Although this intermediate goods index calculation is broader than indicators of Forward_participation and Backward_participation from TiVA database to catch the detail character of the changing pattern of GVC, it at least gives us a picture that China and ASEAN countries are in different positions in the global production network, which lay a solid foundation for the regional production networks.

Overall, the necessity and urgency of strengthening the cooperation of supply chain and value chain within the region, among ASEAN countries and China, 
has been further highlighted because of the epidemic and the reliability governance of GVC. It is essential for China and ASEAN to strengthen cooperation and jointly build a regional value chain. It is firstly the common interests for both China and ASEAN countries to upstream in global supply and value chain. It is also the need of GVC governance for reliability in this Post-COVID Era. What's more, the complementary GVC position and division of labor has already laid the solid foundation for the regional value chain.

\section{Toward Regional Value Chain: Some Policy Implications}

By calculating the proportion of intermediate goods on global level, regional level and country level respectively using newly available data, this paper discusses how COVID-19 impact the GVC and the structure change of the world economy, as well as the position of China and ASEAN countries. The results show that: 1) there has already been a decline in fragmentation of production across borders actually prior to COVID-19 crisis. The pandemic in early 2020 has accelerated this trend. As a global health crisis, The COVID-19 pandemic has surely delivered a profound external shock to global value chains from both supply and demand side, which changing the arrangement for the GVC governance of the MNEs from lower cost to reliability in the long term. 2) ASEAN countries and China has been greatly participated in GVC, but at the relatively lower-end position. Therefore, to strengthen cooperation and jointly build a regional value chain for China and ASEAN is not only the need of GVC governance for reliability in this Post-COVID Era, but also the common interests for both China and ASEAN countries to upstream in global value chain.

\subsection{Strengthen Regional Cooperation under ACFTA, RCEP, the Belt \& Road Initiative, and Other Subregional Mechanisms to Maintain an Open Trade and Investment Environment}

In order to build a reliable regional value chain among ASEAN countries and China in this post-COVID era, the governments should strengthen regional cooperation under free trade agreement and cooperation mechanism such as ASEAN-China FTA, RCEP, the Belt \& Road Initiative, as well as other subregion mechanisms, especially on two aspects: 1) trade facilitation such as the smooth functioning of international transport and customs to maintain the operation of GVCs; 2) provisions for the smooth operations of GVCs in agreement negotiation if possible.

\subsection{Build a Multi-Tiered Industrial Cooperation to Secure Supply Chain and Distribution Channels}

First, the governments could promote standards and regional cooperation mechanism of medical products on $\mathrm{R} \& \mathrm{D}$, production and logistics etc. in order to encounter with the undergoing outbreak. Furthermore, the governments could consider industrial cooperation on textile production, automobile/car manufacture, and conduct docking and complete value chain layout design and research 
among ASEAN countries and China from both industry and firm level.

For companies, creating a comprehensive view of the supply chain through detailed sub-tier mapping is also critical to secure the supply chain. After mapping upstream suppliers, downstream companies need to understand their production footprint, financial stability, and business continuity plans. However, most companies are still in the early stages of their efforts to connect the entire value chain with a seamless flow of data.

\subsection{Strengthen Regional Cooperation on Digital Economy}

First of all, as digital can deliver major benefits to efficiency and transparency that are yet to be fully realized in global value chain, the governments could help to develop and construct information system or digital platforms for risk and production management. For instance, consumer goods giant Procter \& Gamble, has a centralized control tower system that provides a company-wide view across geographies and products. It integrates real-time data, from inventory levels to weather forecasts, for its own plants as well as suppliers and distributors. When a problem occurs, the system can run scenarios to identify the most effective solution. In China and ASEAN countries case, not only help with the firm system, information sharing platforms from country level would also be helpful so that policy coordination on regional GVC could maximum the efficiency.

Second, ASEAN countries and China could strengthen cooperation on digital industries such as online education, AI, ICT infrastructure cooperation and other relating segments.

\subsection{Strengthen Capacity for Scientific and Technological Innovation and Increase the Added Value of Products}

In this COVID-19 outbreak, science and technology, especially medical technology innovation and high-end medical manufacturing played a very important role. China and ASEAN should strengthen technological cooperation and innovation so as to improve the added value of the products and upgrade the position of GVC.

\section{Conclusion}

In order to strengthen regional supply chain and value chain cooperation between China and ASEAN, especially in this post-COVID-19 era, to achieve economic recovery, this paper tries to sum up how the COVID pandemic impacts the global value chain, and then discuss the position of China and ASEAN countries in the global value chain using the newly available data; thus, shed light on the policy implication for the future cooperation of China and ASEAN to build a "regional" global value chain.

The COVID-19 pandemic has delivered a profound shock to the global value chain. The structure of the world economy and GVC is getting more regional. East Asia has been playing an even more important role in GVC. The arrange- 
ment for the GVC governance has been changed from lower cost to reliability in the long term. As a result, countries that could maintain stable open policies, effectively control the epidemic, and are relatively closer as well as with fewer transport risks, have become the first choice for multinational corporations to further diversify their global supply chains so that they can ensure the long-term survival and sustainable development of their GVCs.

ASEAN countries and China has greatly participated in GVC, but at the relatively lower-end position. Therefore, to strengthen cooperation and jointly build a regional value chain for China and ASEAN is not only the need of GVC governance for reliability in this Post-COVID Era but also the common interests for both China and ASEAN countries to upstream in the global value chain.

In order to build a reliable regional value chain among ASEAN countries and China in this post-COVID era, first of all, the governments should strengthen regional cooperation under free trade agreement and cooperation mechanisms such as ASEAN-China FTA, RCEP, the Belt \& Road Initiative, as well as other subregion mechanisms, especially on trade facilitation such as the smooth functioning of international transport and customs to maintain the operation of GVCs. Second, policymakers could promote building multi-tiered industrial cooperation to secure supply chain and distribution channels. Third, ASEAN countries and China could strengthen cooperation on digital industries such as online education, AI, ICT infrastructure cooperation and other relating segments. Last but not the least, China and ASEAN should strengthen technological cooperation and innovation so as to improve the added value of the products and upgrade the position of GVC.

\section{Acknowledgements}

This paper is supported by the Scientific Research Innovation Project of the Fundamental Research Funds for the Central Universities (ID: 3162020ZYKB03).

\section{Conflicts of Interest}

The author declares no conflicts of interest regarding the publication of this paper.

\section{References}

De Backer, K., \& Miroudot, S. (2013). Mapping Global Value Chains. OECD Trade Policy Papers, No. 159, OECD Publishing. https://doi.org/10.1787/5k3v1trgnbr4-en

Gereffi, G. (1994). The Organisation of Buyer-Driven Global Commodity Chains: How U.S. Retailers Shape Overseas Production Networks. In G. Gereffi, \& M. Korzeniewicz (Eds.), Commodity Clains and Global Capitalism (pp. 95-122), Praeger.

Gereffi, G., Humphrey, J., Kaplinsky, R., \& Sturgeon, T.J. (2001). Introduction: Globalisation, Value Chains and Development. IDS Bulletin, 32, 1-8. https://doi.org/10.1111/j.1759-5436.2001.mp32003001.x

Gereffi, G., Humphrey, J., \& Sturgeon, T. (2005). The Governance of Global Value Chains. Review of International Political Economy, 12, 78-104. 


\section{https://doi.org/10.1080/09692290500049805}

Koopman, R., Wang, Z., \& Wei, S. J. (2012). Estimating Domestic Content in Exports When Processing Trade Is Pervasive. Journal of Development Economics, 99, 178-189. https://doi.org/10.1016/j.jdeveco.2011.12.004

OECD (2020). COVID-19 and Global Value Chains: Policy Options to Build More Resilient Production Networks, 3 June.

https://www.oecd.org/coronavirus/policy-responses/covid-19-and-global-value-chainspolicy-options-to-build-more-resilient-production-networks-04934ef4/

Sturgeon, T. J., \& Memedovic, O. (2010). Mapping Global Value Chains-Intermediate Goods Trade and Structural Change in the World Economy. Development Policy and Strategic Research Branch Working Paper, UNIDO.

UNIDO (2002). Industrial Development Report 2002/2003.

https://www.unido.org/resources/publications/publications-type/sales-publications/ind ustrial-development-report-2002-2003 